\title{
PENGARUH MODEL EXPERIENTIAL LEARNING TERHADAP MOTIVASI DAN PRESTASI BELAJAR MATEMATIKA SISWA KELAS VIII SMP NEGERI 1 SAWAN
}

\author{
P Y Paramita, I G P Suharta, I N Gita \\ Jurusan Matematika \\ Universitas Pendidikan Ganesha \\ Singaraja, Indonesia \\ e-mail: yuliaparamita44@gmail.com, putu.suharta@undiksha.ac.id, nyoman.gita@undiksha.ac.id
}

\begin{abstract}
Abstrak
Penelitian ini bertujuan untuk mengetahui pengaruh model experiential learning terhadap motivasi dan prestasi belajar matematika siswa. Penelitian ini merupakan penelitian eksperimen semu dengan rancangan post test only control group design. Populasi penelitian ini adalah siswa kelas VIII SMP Negeri 1 Sawan tahun pelajaran 2018/2019 sebanyak 10 kelas dengan jumlah siswa 306 orang. Uji kesetaraan menggunakan uji ANAVA dan sampel dipilih dengan teknik cluster random sampling. Data motivasi belajar matematika siswa dikumpulkan dengan menggunakan angket motivasi belajar dan data prestasi belajar matematika siswa dikumpulkan dengan menggunakan tes prestasi belajar. Data yang diperoleh dianalisis menggunakan uji MANOVA dengan taraf signifikansi $5 \%$. Hasil pengujian hipotesis menunjukkan bahwa: (1) terdapat perbedaaan motivasi dan prestasi belajar matematika siswa yang mengikuti pembelajaran dengan model experiential learning dengan siswa yang mengikuti pembelajaran konvensional; (2) terdapat perbedaaan motivasi belajar matematika siswa yang mengikuti pembelajaran dengan model experiential learning dengan siswa yang mengikuti pembelajaran konvensional; dan (3) terdapat perbedaaan prestasi belajar matematika siswa yang mengikuti pembelajaran dengan model experiential learning dengan siswa yang mengikuti pembelajaran konvensional. Dengan demikian dapat disimpulkan bahwa model experiential learning berpengaruh positif terhadap motivasi dan prestasi belajar matematika.
\end{abstract}

Kata kunci : model experiential learning, prestasi belajar matematika, motivasi belajar matematika.

\begin{abstract}
This study aims to determine the effect of experiential learning models on students' motivation and mathematics learning achievement. This research is a preexperimental study with a post-test only control group design. The population of this study was the VIII grade students of SMP Negeri 1 Sawan in academic year $2018 / 2019$ as many as 10 classes with 306 students. The equality test uses ANAVA test and the sample was selected by cluster random sampling technique. The data on students' mathematics learning motivation were collected using a learning motivation questionnaire and students' mathematics learning achievement data were collected using a learning achievement test. The data obtained were analyzed using the MANOVA test with a significance level of $5 \%$. The results of hypothesis testing indicate that: (1) there were differences in motivation and mathematics learning achievement of students who take learning with experiential learning models with students who follow conventional learning; (2) there were differences in the motivation to learn mathematics of students who attend learning with experiential learning models with students who follow conventional learning; and (3) there were differences in mathematics learning achievement of students who take part in learning with experiential learning models with students who take conventional learning. Thus it can be concluded that the experiential learning model gives positive influences motivation and learning achievement in mathematics.
\end{abstract}

Keywords : experiential learning model, mathematics learning achievement, motivation to learn mathematics 


\section{PENDAHULUAN}

Pendidikan merupakan hal yang sangat penting dan perlu mendapatkan perhatian yang serius dalam rangka meningkatkan sumber daya manusia. Dalam UUD No. 20 tahun 2003 tentang Sistem Pendidikan Nasional, menyatakan pendidikan merupakan usaha sadar dan terencana untuk mewujudkan suasana belajar dan proses pembelajaran agar peserta didik secara aktif mengembangkan potensi dirinya untuk memiliki kekuatan spiritual keagamaan, pengendalian diri, kepribadian, kecerdasan, akhlak mulia serta keterampilan yang diperlukan dirinya, masyarakat, bangsa, dan negara. Melalui pendidikan diharapkan dapat mengembangkan potensi sumber daya manusia di Indonesia sehingga mampu bersaing dengan negara lainnya yang lebih maju dari segi sumber daya manusianya.

Namun faktanya, kualitas pendidikan di Indonesia masih tergolong rendah terutama pada bidang matematika. Kemendikbud memaparkan mengenai peringkat prestasi belajar matematika Indonesia melalui pemeringkatan Programme for Internasional Student Assesment (PISA) yang termuat dalam kemdikbud.go.id bahwa pencapaian PISA pada tahun 2015 mengalami peningkatan dari tahun 2012 secara umum khususnya untuk matematika. Pada tahun 2012 kompetensi matematika yang diperoleh Indonesia adalah 375 poin sedangkan pada tahun 2015 terjadi peningkatan sebanyak 11 poin menjadi 386 poin. Selain itu, Organisation for Economic Cooperation an Development (OECD) yang termuat dalam www.oecd.org juga memaparkan bahwa pada tahun 2015 Indonesia berhasil memperoleh peringkat ke-63 dari 72 negara. Walaupun Indonesia mengalami peningkatan pencapaian PISA dari tahun 2012 ke tahun 2015, tetapi peringkat Indonesia masih tertinggal jauh dibandingkan dengan Negara ASEAN lainnya.

Senada dengan pernyataan di atas, kemendikbud juga memaparkan mengenai peringkat prestasi matematika Indonesia berdasarkan Trends in Mathematics and Science Study (TIMSS). Berdasarkan hasil TIMSS pada tahun 2015 skor matematika yang berhasil diperoleh Indonesia adalah 397 poin dengan skor rata-ratanya sebesar 26 poin. Skor rata-rata yang diraih Indonesia masih dibawah skor rata-rata Internasional yaitu 50 poin. Menurut TIMSS, Indonesia pada tahun 2015 meraih peringkat 45 dari 50 negara. Peringkat Indonesia ini tentu masih jauh tertinggal jika dibandingkan dengan Negara ASEAN lainnya. Berdasarkan fakta-fakta di atas, dapat dilihat bahwa prestasi belajar matematika siswa sangat rendah. Hal ini tentu menjadi tugas penting bagi bangsa Indonesia untuk meningkatkan prestasi belajar matematika siswa.

Selain rendahnya prestasi belajar matematika siswa, permasalahan lain yang sering muncul adalah rendahnya motivasi belajar matematika siswa. Motivasi belajar matematika merupakan suatu dorongan yang berasal dari dalam/luar diri siswa yang mendorong siswa untuk aktif berpartisipasi dalam kegiatan pembelajaran matematika, sehingga dapat mencapai tujuan yang diinginkan oleh siswa. Kurangnya motivasi belajar matematika sering disebabkan karena suasana dari kegiatan pembelajaran matematika yang membosankan.

Depdiknas (2006) menjelaskan bahwa pelajaran matematika bertujuan agar siswa mampu memahami konsep matematika, mampu melakukan manipulasi matematika dalam membuat generalisasi, mengkomunikasikan gagasan, dan memiliki sikap menghargai kegunaan matematika dalam kehidupan. Senada dengan pernyataan tersebut, National Council of Teacher of Mathematics (NCTM, 2000) menjelaskan bahwa tujuan pembelajaran matematika adalah belajar untuk berkomunikasi, belajar untuk bernalar, belajar untuk memecahkan masalah, belajar untuk mengaitkan ide, dan pembentukan sikap positif terhadap matematika. Namun, materi pelajaran matematika yang bersifat abstrak dan dipenuhi dengan banyak 
rumus-rumus ataupun lambang-lambang seringkali mengakibatkan siswa kesulitan untuk memahami materi yang diajarkan.

Salah satu cara yang dapat ditempuh guru adalah dengan cara menerapkan model pembelajaran inovatif yang dapat menumbuhkan motivasi belajar matematika siswa dan juga dapat meningkatkan prestasi belajar matematika siswa. Model experiential learning merupakan model pembelajaran yang menekankan pengalaman siswa secara langsung pada proses belajar untuk membangun pengetahuan dan keterampilan siswa. Model pembelajaran ini terdiri dari empat tahapan, yaitu: concrete experience (pengalaman konkret), reflective observation (observasi dan refleksi), abstract conceptualization (konseptualisasi abstrak), dan active experimentation (ekperimentasi aktif).

Tahap pertama dari model experiential learning adalah concrete experience (pengalaman konkret). Pada tahap ini siswa akan membentuk pemahaman dan pengetahuan dari kejadian/peristiwa berdasarkan pengalaman yang siswa alami sebagaimana adanya.

Tahap kedua dari model experiential learning adalah reflective observation (observasi dan refleksi). Tahap observasi dan refleksi merupakan tahap siswa melakukan observasi dengan menggunakan panca indra, perasaan, ataupun alat bantu lainnya yang kemudian direfleksikan untuk menarik pelajaran dari peristiwa tersebut.

Tahap ketiga adalah tahap abstract conceptualization (konseptualisasi abstrak) merupakan tahap siswa melakukan generalisasi terhadap konsepkonsep yang diperoleh dari hasil observasi dan refleksi untuk membentuk konsepkonsep matematika yang bersifat abstrak. Tahap yang terakhir adalah tahap active experimentation (ekperimentasi aktif). Pada tahap ini siswa mengaplikasikan konsep-konsep, teori-teori, dan aturanaturan yang dibentuk dari tahapan sebelumnya ke dalam situasi nyata.

Berdasarkan uraian di atas, maka penulis tertarik untuk melakukan penelitian yang berjudul "Pengaruh Model
Pembelajaran Experiential Learning terhadap Motivasi dan Prestasi Belajar Matematika Siswa Kelas VIII SMP Negeri 1 Sawan".

\section{METODE PENELITIAN}

Jenis penelitian yang dilaksanakan adalah penelitian eksperimen semu (quasi experimen) dengan desain penelitian posttest-only control group design. Penelitian eksperimen semu digunakan untuk memperoleh informasi yang dapat diperoleh dengan eksperimen yang sebenarnya dalam keadaan yang tidak memungkinkan untuk mengontrol dan/atau memanipulasi semua variabel yang relevan (Suryabrata, 2006). Penelitian ini bertujuan untuk mengetahui pengaruh model experiential learning terhadap motivasi dan prestasi belajar matematika siswa Kelas VIII SMP Negeri 1 Sawan.

Populasi penelitian ini adalah siswa Kelas VIII SMP Negeri 1 Sawan semester ganjil tahun pelajaran 2018/2019. Teknik yang digunakan untuk pemilihan sampel dalam penelitian ini adalah teknik Cluster Random Sampling. Pemilihan sampel dengan teknik ini dilakukan jika kelas dalam populasi yang akan diambil sebagai sampel memiliki karakteristik yang homogen/relatif homogen (tidak ada kelas unggulan) (Lestari, 2017). Sebelum dilakukan penarikan sampel, terlebih dahulu dilakukan uji kesetaraan untuk mengetahui apakah populasi tersebut memiliki kemampuan yang setara atau tidak. Dalam penelitian ini, uji kesetaraan dilakukan dengan menggunakan uji analisis varians (ANAVA) satu jalur. Hasil perhitungan dari uji ANAVA adalah $F_{\text {hitung }}=$ $0,0318<F_{\text {tabel }}=1,9116$, artinya seluruh kelas populasi setara. Karena seluruh kelas populasi sudah setara, selanjutnya dilakukan pengundian untuk menentukan sampel penelitian. Dari hasil pengundian tersebut terpilih Kelas VIII I sebagai kelompok kontrol dan Kelas VIII J sebagai kelompok eksperimen.

Variabel bebas dalam penelitian ini adalah model experiential learning yang diterapkan pada kelompok eksperimen dan model pembelajaran konvensional 
yang diterapkan pada kelompok kontrol. Variabel terikat dalam penelitian ini adalah motivasi dan prestasi belajar matematika.

Penelitian ini memerlukan dua jenis data yaitu data motivasi belajar dan data prestasi belajar matematika. Instrumen yang digunakan untuk memperoleh data motivasi belajar matematika siswa adalah angket motivasi belajar matematika. Jenis angket yang digunakan menggunakan skala likert yang terdiri dari 25 butir pernyataan. Indikator yang digunakan untuk mengukur motivasi belajar matematika, yaitu adanya hasrat dan keinginan berhasil, adanya dorongan dan kebutuhan dalam belajar, adanya harapan dan cita-cita masa depan, adanya penghargaan dalam belajar, adanya kegiatan yang menarik dalam belajar, dan adanya lingkungan belajar yang kondusif, sehingga memungkinkan seorang siswa dapat belajar dengan baik (Uno, 2015).

Instrumen yang digunakan untuk memproleh data prestasi belajar matematika siswa adalah tes prestasi belajar matematika. Tes prestasi belajar matematika yang diberikan berbentuk tes uraian. Tes uraian digunakan karena tes uraian memungkinkan kita untuk dapat melihat sejauh mana pemahaman siswa terhadap materi yang telah mereka pelajari.

Data motivasi dan prestasi belajar matematika yang diperoleh dari masingmasing kelas sampel selanjutnya di analisis menggunakan uji MANOVA (Multivariate Analysis of Variance). Sebelum pengujian hipotesis menggunakan uji MANOVA dilakukan uji normalitas sebaran data menggunakan uji Kolmogorov Smirnov, uji homogenitas varians menggunakan uji Levene, uji homogenitas matriks varian/covarian menggunakan uji Box's $M$, dan uji kolinearitas variabel terikat menggunakan rumus korelasi product moment. Semua pengujian hipotesis menggunakan taraf signifikansi $5 \%$.

\section{HASIL DAN PEMBAHASAN}

Adapun hasil dari analisis data motivasi dan data prestasi belajar matematika siswa akan dipaparkan sebagai berikut.

Tabel 1 Rangkuman Hasil Analisis Data Motivasi dan Prestasi Belajar Matematika

\begin{tabular}{lcc}
\hline Kelompok & $\begin{array}{c}\text { Rata-rata } \\
\text { Skor } \\
\text { Motivasi }\end{array}$ & $\begin{array}{c}\text { Rata-rata } \\
\text { Skor } \\
\text { Prestasi }\end{array}$ \\
\hline Eksperimen & 88,52 & 46,39 \\
\hline Kontrol & 80,47 & 35,63 \\
\hline
\end{tabular}

Berdasarkan Tabel 1 di atas, terlihat bahwa rata-rata skor motivasi dan prestasi belajar matematika siswa yang dibelajarkan dengan model experiential learning pada kelompok eksperimen lebih tinggi daripada rata-rata skor motivasi dan prestasi belajar matematika siswa pada kelompok kontrol.

Hasil pengujian normalitas sebaran data menggunakan uji Kolmogorov Smirnov menunjukkan bahwa nilai-nilai statistik yang diperoleh memiliki nilai $D_{\text {hitung }}$ yang lebih kecil dibandingkan dengan nilai $D_{\text {tabel. }}$ Hal ini menunjukkan bahwa data motivasi dan prestasi belajar matematika siswa kelompok eksperimen dan kelompok kontrol memiliki sebaran data yang berdistribusi normal. Rangkuman hasil pengujian normalitas sebaran data dengan uji Kolmogorov Smirnov disajikan pada Tabel 2 berikut.

Tabel 2 Rangkuman Hasil Uji Kolmogorov Smirnov

\begin{tabular}{lcc}
\hline Kelompok & $\begin{array}{c}\text { Motivasi } \\
\text { Belajar } \\
\text { Matematika }\end{array}$ & $\begin{array}{c}\text { Prestasi } \\
\text { Belajar } \\
\text { Matematika }\end{array}$ \\
\hline Eksperimen & 0,1108 & 0,1139 \\
\hline Kontrol & 0,1156 & 0,1054 \\
\hline
\end{tabular}

Hasil pengujian homogenitas varians menggunakan uji Levene menunjukan hasil bahwa nilai-nilai statistik yang diperoleh memiliki nilai $W$ yang lebih kecil dibandingkan dengan nilai $F_{\text {tabel }}=4,0040$. Berdasarkan hasil perhitungan nilai $W$ data motivasi dan prestasi belajar matematika siswa berturut-turut adalah 0,0391 dan 0,5016 . Hal ini menunjukkan 
bahwa data motivasi dan prestasi belajar matematika siswa kelompok eksperimen dan kelompok kontrol memiliki varians yang homogen.

Hasil pengujian homogenitas matriks varian/kovarian antar variabel terikat menggunakan uji Box's M memiliki nilai 2,343 dengan signifikansi sebesar 0,521 yang lebih tinggi dari 0,05 . Hal ini menunjukkan bahwa matriks varian/kovarian antar variabel terikat homogen.

Hasil pengujian kolinearitas data motivasi dan prestasi belajar matematika siswa kelompok eksperimen dengan menggunakan rumus korelasi product moment adalah $r_{y 1 y 2}=0,5074$ yang kurang dari 0,800 . Sedangkan hasil Hasil uji kolinearitas data motivasi dan prestasi belajar matematika siswa kelompok kontrol adalah $r_{y 1 y 2}=0,7046$ yang kurang dari 0,800. Oleh karena itu, dapat disimpulkan bahwa $r_{y 1 y 2}$ antara sesama variabel terikat tidak tejadi koliniearitas.

Pengujian hipotesis penelitian dilakukan dengan menggunakan uji MANOVA (Multivariate Analysis of Variance). Karena pada pemaparan sebelumnya uji prasyarat dari uji MANOVA telah terpenuhi, sehingga pengujian hipotesis penelitian dengan menggunakan uji MANOVA dapat dilanjutkan. Adapun hasil pengujian hipotesis tersebut secara berurutan adalah sebagi berikut.

Tabel 3 Hasil Analisis Multivariate

\begin{tabular}{|c|c|c|c|}
\hline Effect & Value & $F$ & Sig. \\
\hline Pillai's Trace & 0,258 & 10,104 & 0,000 \\
\hline Wilks' Lambda & 0,742 & 10,104 & 0,000 \\
\hline $\begin{array}{l}\text { Hotelling's } \\
\text { Trace }\end{array}$ & 0,348 & 10,104 & 0,000 \\
\hline $\begin{array}{l}\text { Roy's Largest } \\
\text { Root }\end{array}$ & 0,348 & 10,104 & 0,000 \\
\hline
\end{tabular}

Berdasarkan hasil analisis pada Tabel 3 di atas, diperoleh nilai $F$ untuk Wilks' Lambda memiliki signifikasi 0,000 yang kurang dari 0,05 , artinya nilai $F$ untuk Wilks' Lambda signifikan. Dengan demikian, dapat disimpulkan bahwa terdapat perbedaan motivasi dan prestasi belajar matematika siswa yang mengikuti pembelajaran dengan model experiential learning dengan siswa yang mengikuti pembelajaran konvensional.

Tabel 4 Hasil Test of Between Subjects Effects

\begin{tabular}{lllll}
\hline Source & $\begin{array}{c}\text { Dependent } \\
\text { Variable }\end{array}$ & $d f$ & $F$ & Sig. \\
\hline Corrected & MOTIVASI & 1 & 11,838 & 0,001 \\
Model & PRESTASI & 1 & 19,730 & 0,000 \\
\hline Intercept & MOTIVASI & 1 & $5,217 \mathrm{E} 3$ & 0,000 \\
& PRESTASI & 1 & $1,148 \mathrm{E} 3$ & 0,000 \\
\hline KELOMPOK & MOTIVASI & 1 & 11,838 & 0,001 \\
& PRESTASI & 1 & 19,730 & 0,000 \\
\hline Error & MOTIVASI & 59 & & \\
& PRESTASI & 59 & & \\
\hline \multirow{2}{*}{ Total } & MOTIVASI & 61 & & \\
\hline Corrected & MRESTASI & 61 & & \\
Total & PRESTASI & 60 & & \\
\hline
\end{tabular}

Pengujian hipotesis kedua dan ketiga dengan Test of Between Subjects Effects dapat dilihat pada Tabel 4. Berdasarkan hasil analisis Test of Between Subjects Effects pada Tabel 4 di atas menunjukkan bahwa terdapat perbedaan motivasi belajar matematika siswa kelas VIII SMP Negeri 1 Sawan yang mengikuti pembelajaran dengan model pembelajaran experiential learning dengan siswa yang mengikuti pembelajaran konvensional menghasilkan nilai $F$ sebesar 11,838 dengan signifikansinya sebesar 0,001 (sig. $F<$ 0,05). Hal ini menunjukkan bahwa terdapat perbedaan motivasi belajar matematika siswa yang mengikuti pembelajaran dengan model experiential learning dengan siswa yang mengikuti pembelajaran konvensional.

Hasil analisis Test of Between Subjects Effects pada Tabel 4 juga menunjukkan bahwa terdapat perbedaan prestasi belajar matematika siswa kelas VIII SMP Negeri 1 Sawan yang mengikuti 
pembelajaran dengan model pembelajaran experiential learning dengan siswa yang mengikuti pembelajaran konvensional menghasilkan nilai $F$ sebesar 19,730 dengan signifikansinya sebesar 0,000 (sig. $F<0,05$ ). Hal ini menunjukkan bahwa terdapat perbedaan prestasi belajar matematika siswa yang mengikuti pembelajaran dengan model experiential learning dengan siswa yang mengikuti pembelajaran konvensional.

Berdasarkan hasil penelitian, maka dapat diambil kesimpulan bahwa model experiential learning berpengaruh positif terhadap motivasi dan prestasi belajar matematika. Adapun beberapa alasan yang dapat dijadikan dasar kesimpulan bahwa model experiential learning berpengaruh positif terhadap motivasi dan prestasi belajar matematika. Dilihat dari segi landasan teori, model experiential learning merupakan model pembejaran yang dikembangkan oleh David Kolb berdasarkan teorinya yaitu Experiential Learning Theory (ELT) yang menekankan pengalaman dalam proses belajar siswa baik secara formal maupun informal. Hal ini juga sejalan dengan teori belajar kontruktivisme yang mengarahkan siswa untuk membangun makna dari pengalaman belajar mereka.

Pengalaman belajar siswa nantinya akan diarahkan untuk membangun pemahaman dan pengetahuan yang dimiliki siswa. Selama proses pembelajaran siswa akan dilatih untuk membentuk dan mengembangkan pengetahuan melalui pengalaman, melakukan refleksi dan observasi terhadap pengalaman, dan pembetukan konsep sebagai hasil dari proses refleksi dan observasi. Oleh sebab itu, pengalaman akan memiliki peran sentral dalam proses pembelajaran dan menjadi dasar dari setiap langkah pembelajaran dengan menggunakan model experiential learning.

Sebagai bentuk pembanding, pembelajaran dengan model pembelajaran konvensional kurang mampu untuk meningkatkan motivasi dan prestasi belajar matematika siswa. Hal ini disebabkan karena pada kelompok kontrol pembelajaran dilakukan dengan berbasis pada masalah yang tidak semua siswa mampu untuk menyelesaikan setiap permasalahan yang diberikan. Kurangnya minat siswa dalam mencari informasi secara mandiri untuk menyelesaikan permasalahan yang diberikan menjadi masalah utama selama kegiatan pembelajaran. Selain itu, beberapa kelompok terlihat lebih memilih bertanya kepada kelompok lain yang sudah menyelesaikan permasalahan tersebut. Guru sudah mencoba untuk meningkatkan motivasi dan prestasi belajar siswa namun dalam pelaksaannya masih belum optimal.

\section{SIMPULAN DAN SARAN}

Berdasarkan hasil penelitian dan pembahasan maka dapat diuraikan tiga simpulan, yaitu: (1) terdapat perbedaan motivasi dan prestasi belajar matematika siswa yang mengikuti pembelajaran dengan model experiential learning dengan siswa yang mengikuti pembelajaran konvensional; (2) terdapat perbedaan motivasi belajar matematika siswa yang mengikuti pembelajaran dengan model experiential learning dengan siswa yang mengikuti pembelajaran konvensional; dan (3) terdapat perbedaan prestasi belajar matematika siswa yang mengikuti pembelajaran dengan model experiential learning dengan siswa yang mengikuti pembelajaran konvensional.

Saran yang dapat disampaikan dalam penelitian ini adalah sebagai berikut. Pertama, Bagi praktisi pendidikan khususnya guru mata pelajaran matematika yang mengalami masalah permasalahan rendahnya motivasi dan prestasi belajar matematika siswa, dapat menerapkan model experiential learning dalam proses pembelajaran di kelas sebagai salah satu alternatif untuk menyelesaikan masalah tersebut. Kedua, Bagi peneliti lain yang tertarik untuk melakukan penelitian lebih lanjut terhadap penerapan model experiential learning dalam proses pembelajaran disarankan untuk dapat melakukan penelitian terhadap pendekatan pembelajaran yang berbeda atau pada jenjang yang berbeda. 


\section{DAFTAR PUSTAKA}

Depdiknas. 2006. Permendiknas Republik Indonesia No. 22 Tahun 2006 Tentang Standar Isi untuk Satuan Pendidikan Dasar dan Menengah. Jakarta: Depdiknas.

Kemendikbud. 2016. "Tentang TIMSS". Tersedia pada http://puspendik.kemdikbud.go.id/se minar/upload/Hasil\%20Seminar\%20 Puspendik\%202016/TIMSS\%20infog raphic.pdf (diakses tanggal 10 Oktober 2017).

Lestari, Karunia Eka., dkk. 2017. Penelitian Pendidikan Matematika. Bandung: PT Refika Aditama.

NCTM. 2000. Principles and Standards for School Mathematics. Reston, VA: NCTM

OECD. 2016. PISA 2015 Results in Focus. Tersedia pada: https://www.oecd.org/pisa/pisa2015-results-in-focus.pdf (Diakses pada 4 September 2017)

Suryabrata, Sumadi. 2006. Metodologi Penelitian. Jakarta: PT Raja Grafindo Persada.

Undang-undang Republik Indonesia No. 20 Tahun 2003 tentang Sistem Pendidikan Nasional. Jakarta.

Uno, Hamzah B., dkk. 2015. Variabel Penelitian dalam Pendidikan dan Pembelajaran. Jakarta: PT Ina Publikatama. 